\title{
SISTEM PENDUKUNG KEPUTUSAN PERAMALAN PENDAPATAN DI DINAS PENANAMAN MODAL DAN PELAYANAN PERIZINAN TERPADU SATU PINTU KABUPATEN BULELENG DENGAN METODE LEAST SQUARE]
}

\author{
Ni Ketut Ayu Indra Cahyani ${ }^{1}$, I Made Putrama ${ }^{2}$, I Made Agus Wirawan ${ }^{3}$ \\ 1,2,3 Universitas Pendidikan Ganesha \\ Singaraja, Bali \\ e-mail: ayuindra.c@gmail.com ${ }^{1,}$, made.putrama@undiksha.ac.id ${ }^{2}$, \\ agus.wirawan@undiksha.ac.id ${ }^{3}$
}

\begin{abstract}
Abstrak
Penelitian ini bertujuan untuk (1) merancang Sistem Pendukung Keputusan Peramalan Pendapatan di Dinas Penanaman Modal dan PPTSP Kabupaten Buleleng dengan Metode Least Square dan (2) mengimplementasikan Sistem Pendukung Keputusan Peramalan Pendapatan di Dinas Penanaman Modal dan PPTSP Kabupaten Buleleng dengan Metode Least Square. Dinas Penanaman Modal dan PPTSP Kabupaten Buleleng merupakan salah satu Organisasi Perangkat Daerah (OPD) yang ada di Kabupaten Buleleng dalam menangani penanaman modal, perizinan dan non perizinan sehingga menyumbangkan Pendapatan Asli Daerah (PAD) bagi Kabupaten Buleleng.

Sistem Pendukung Keputusan Peramalan Pendapatan ini terdiri dari 3 (tiga) entitas yaitu Bendahara Penerimaan, PPK (Pejabat Penatausahaan Keuangan) dan Kepala Dinas. Realisasi pendapatan akan diinput oleh bendahara penerimaan kemudian divalidasi oleh PPK selaku admin dan selanjutnya berdasarkan data pendapatan yang valid maka diramalkan pendapatan untuk periode bulan berikutnya. Hal ini akan digunakan sebagai rekomendasi bagi Kepala Dinas untuk menentukan target tahunan pendapatan berdasarkan atas data realisasi pada tahun sebelumnya. Perhitungan peramalan pendapatan dalam Sistem Pendukung Keputusan ini menggunakan metode least square. Metode ini digunakan karena metode ini menghasilkan tren yang paling cocok dibandingkan dengan metode-metode lainnya. Hal ini terbukti dari perhitungan rata-rata kesalahan yaitu MAD, RMSE dan MAPE menunjukkan bahwa metode least square memiliki rata-rata kesalahan yang lebih kecil jika dibandingkan dengan rata-rata kesalahan perhitungan dengan metode Double Moving Average dan Double Exponential Smoothing. Hasil penelitian ini adalah sistem sudah berhasil dirancang dan diimplementasikan dengan baik dengan respon pengguna yang memilih skor 5 adalah $71,11 \%$ dan memilih skor 4 adalah $28,89 \%$ serta hasil uji akurasi sistem yaitu $66,34 \%$ dengan rata-rata kesalahan $34,66 \%$.
\end{abstract}

Kata kunci: Sistem Pendukung Keputusan, Peramalan Pendapatan, Least Square

\begin{abstract}
This research aims to (1) to design a Decision Support Decision Support System in Capital Investment and PPTSP Buleleng Regency with Least Square Method and (2) Implementation Decision Support Decision Support System in the Capital Investment and PPTSP Buleleng Regency with Least Square Method. The Capital Investment and PPTSP Buleleng Regency is one of the Regional Devices Organizations (OPDs) in Buleleng Regency in dealing with investment, licensing and non-licensing, contributing Regional Revenue (PAD) to Buleleng Regency
\end{abstract}


Decision Support System Forecasting This income consists of 3 (three) entities namely the Receiver Treasurer, PPK (Financial Administration Officer) and Head of Department. Earnings realization will be inputted by the receiver treasurer then validated by PPK as admin and subsequently based on valid income data then predicted revenue for next month period. This will be used as a recommendation for the Head of Department to determine the annual revenue target based on realization data in the previous year. Calculation of income forecasting in Decision Support System uses least square method. This method is used because this method yields the most suitable trend compared to other methods. This is evident from the calculation of the average error of MAD, RMSE and MAPE indica cating that the least square method has a smaller average error compared to the average error calculation using the Double Moving Average and Double Exponential Smoothing method. The result of this research is the system has been successfully designed and implemented well with the user's response that choose score 5 is $71,11 \%$ and choose score 4 is $28,89 \%$ and result of system accuracy test that is $66,34 \%$ with error average $34,66 \%$.

Keywords: Decision Support System, Income Forecasting, Least Square

\section{PENDAHULUAN}

Pendapatan Asli Daerah (PAD) merupakan sumber pendapatan yang sangat penting bagi sebuah daerah untuk membiayai belanjanya. PAD dapat dijadikan sebagai tolak ukur kemandirian suatu daerah. PAD adalah penerimaan yang dihasilkan oleh daerah yang bersangkutan, yang bersumber dari pajak daerah, retribusi daerah, hasil pengolahan kekayaan daerah yang dipisahkan, dan lain-lain PAD yang sah ${ }^{[1]}$. Oleh karena itu pemerintah daerah harus mengoptimalkan segala sumber daya yang ada di daerahnya masing-masing baik itu dari segi pemanfaatan sumber daya alam, sumber daya manusia dan kewenangan dalam hal pemungutan pajak dan retribusi daerah.

Kabupaten Buleleng merupakan salah satu daerah bagian dari Provinsi Bali yang juga melaksanakan otonomi daerah seperti daerah otonom lainnya. Serangkaian pemasukan dari berbagai sektor diharapkan dapat memberikan sumbangan yang maksimal dalam proses pembangunan daerah sehingga otonomi daerah dapat berjalan dengan lancar. Salah satu upaya Pemerintah Kabupaten Buleleng untuk meningkatkan PAD adalah penyelenggaraan pungutan pajak dan retribusi urusan pemerintahan wajib non pelayanan dasar. Dinas Penanaman Modal dan Pelayanan Perizinan Terpadu Satu Pintu merupakan salah satu Satuan Kerja
Perangkat Daerah (SKPD) di lingkup Pemerintahan Kabupaten Buleleng yang memiliki tugas membantu Bupati melaksanakan Urusan Pemerintahan di bidang Penanaman Modal dan Pelayanan Administrasi Perizinan. Dengan adanya penerimaan/pendapatan tersebut diharapkan dapat meningkatkan PAD.

Data yang diperoleh dari Dinas Penanaman Modal dan PPTSP selama periode tahun 2009-2016 menunjukkan bahwa hampir di setiap tahun realisasi pendapatan sudah melampaui target dan bisa dikatakan meningkat. Misalnya pada tahun 2009 realisasi mencapai 235,45\%, hal ini dikarenakan Dinas Penanaman Modal dan PPTSP yang masih bernama KPT (Kantor Pelayanan Terpadu) baru berdiri setahun sebelumnya jadi memang masih belum ada data historis yang bisa dijadikan pedoman. Namun realisasi yang jauh melampaui target juga terjadi di tahun 2011 di mana realisasi mencapai $153,17 \%$ dan pada tahun 2015 lebih signifikan lagi yaitu $172,82 \%$. Namun pada tahun 2014 realisasi pendapatan tidak mencapai target yang sudah ditentukan yaitu masih di angka 99,31\%. Berdasarkan hasil wawancara dengan Kepala Dinas Penanaman Modal dan PPTSP pada tanggal 1 Maret 2017, Bapak I Putu Karuna, SH., yang menyebabkan realisasi tidak memenuhi target pada tahun 2014 karena kurang tepatnya prediksi yang 
dibuat terutama untuk retribusi Izin Mendirikan Bangunan yang menyumbang pendapatan paling besar. Target pada tahun 2014 ditentukan berdasarkan data masa lalu dan melihat realisasi untuk tahun terakhir sesuai dengan insting dan perkiraan sendiri baik itu berkaitan dengan keputusan untuk menaikkan atau menurunkan target berdasarkan pertimbangan tertentu. Penambahan ataupun pengurangan penentuan target setiap tahunnya juga mengacu pada peraturan yang berlaku misalnya saja karena adanya beberapa ijin yang diambil alih oleh Provinsi maupun adanya penambahan sewa reklame sesuai dengan Peraturan Bupati sehingga ini menjadi dasar bagi Kepala Dinas untuk menaikkan target pada Pajak Izin Reklame. Data masa lalu yaitu pada tahun 2013 pelampauan anggaran yang cukup signifikan yaitu pada Retribusi IMB sebesar $147,25 \%$ bahkan untuk Retribusi Izin Usaha Perikanan mencapai $211,30 \%$. Sehingga inilah yang menjadi pertimbangan bagi pengambil keputusan dalam hal ini Kepala Dinas untuk menaikkan target terutama pada kedua Retribusi tersebut termasuk menaikkan target pada Pajak Reklame. Ini berarti prediksi yang dilakukan masih manual. Menganalisis data dalam jumlah besar jika dilakukan secara manual cukup sulit untuk menentukan kecepatan perhitungan ditambah lagi tanpa penggunaan metode yang tepat untuk memprediksi pendapatan. Selain itu analisis manual akan membutuhkan waktu yang lebih lama serta ketelitian yang tinggi supaya tingkat kesalahan yang ditimbulkan tidak terlalu besar.

Salah satu pemanfaatan komputer tersebut adalah adanya Sistem Pendukung Keputusan (Decission Support System). Peramalan merupakan bagian awal dari suatu proses pengambilan keputusan ${ }^{[2]}$. Sebelum mengambil keputusan dalam membuat perencanaan terlebih dulu melakukan peramalan. Karena dengan melakukan peramalan perusahaan dapat memperoleh informasi mengenai perubahan di masa yang akan datang dan menjadi dasar untuk mengambil keputusan dalam membuat perencanaan ${ }^{[3]}$.

Menurut Aswi dan Sukarna, prediksi/peramalan masa depan jarang sekali yang akurat, pelaku peramalan hanya berusaha untuk membuat sekecil mungkin kesalahan ${ }^{[4]}$. Dalam waktu tertentu jumlah penerimaan. Untuk itu perlu adanya proyeksi atau peramalan terhadap jumlah penerimaan pendapatan untuk tahun selanjutnya sehingga dari ramalan hasil penerimaan tersebut bisa ditentukan target penerimaan untuk periode selanjutnya.

Berdasarkan paparan di atas, maka perlu adanya suatu sistem yang membantu memberikan rekomendasi kepada pihak pengambil keputusan di Dinas Penanaman Modal dan PPTSP untuk memprediksi atau meramalkan besarnya pendapatan untuk tahun berikutnya.

\section{METODE}

Data dalam penelitian diperoleh dari hasil wawancara atau interview dengan Kepala Dinas Penanaman Modal dan Pelayanan Perizinan Terpadu Satu Pintu Kabupaten Buleleng yaitu Bapak I Putu Karuna, SH pada tanggal 1 Maret 2017 yang menghasilkan mengenai tata cara penentuan target tiap tahunnya, komparasi target dan realisasi pendapatan serta alasan kenaikan dan penurunan realisasi, permasalahan yang sering dihadapi ketika menentukan target pendapatan setiap tahunnya. Dinas Penanaman Modal dan PPTSP Kabupaten Buleleng sendiri terbentuk berdasarkan pada Peraturan Daerah Kabupaten Buleleng Nomor 13 Tahun 2016 tentang Pembentukan dan Susunan Perangkat Daerah yaitu Dinas Penanaman Modal dan Pelayanan Perizinan Terpadu Satu Pintu yang menangani urusan wajib non pelayanan dasar khususnya di bidang perizinan, non perizinan dan penanaman modal. Saat ini ada 39 jenis izin yang ditangani oleh OPD ini. Namun hanya 6 jenis perizinan yang berbayar yaitu Pajak Reklame, Retribusi IMB (Izin Mendirikan Bangunan, HO (Gangguan), Perikanan, Trayek dan Izin Tempat Penjualan Minuman Beralkohol 
(SITU-MB). Keenam jenis izin inilah yang nantinya menyumbangkan PAD untuk daerah. Dari hasil wawancara dan dokumentasi maka diperoleh data rekap data target dan pendapatan per tahun yakni dari tahun 2009-2016.

Tabel 1. Rekap Target dan Pendapatan Per Tahun 2009-2016

\begin{tabular}{|c|c|c|c|}
\hline \multirow{2}{*}{ NO } & \multirow{2}{*}{ TAHUN } & \multicolumn{2}{|c|}{ PAD } \\
\cline { 3 - 4 } & & TARGET & REALISASI \\
\hline 1 & Tahun 2009 & 889.330 .000 & 2.093 .887 .820 \\
\hline 2 & Tahun 2010 & 1.664 .330 .000 & 2.257 .909 .875 \\
\hline 3 & Tahun 2011 & 1.774 .210 .000 & 2.717 .545 .925 \\
\hline 4 & Tahun 2012 & 3.250 .387 .000 & 3.605 .267 .450 \\
\hline 5 & Tahun 2013 & 4.125 .000 .000 & 5.139 .081 .225 \\
\hline 6 & Tahun 2014 & 5.144 .213 .000 & 5.108 .583 .450 \\
\hline 7 & Tahun 2015 & 5.621 .231 .000 & 9.714 .834 .925 \\
\hline 8 & Tahun 2016 & 5.763 .750 .000 & 6.516 .130 .500 \\
\hline
\end{tabular}

(sumber: DPMPPTSP, 2017)

Dari rekap data target dan pendapatan tersebut maka bisa dilihat bahwa trend dalam penentuan target dan realisasi pendapatan cenderung meningkat dari tahun ke tahun. Berikut adalah diagram yang menunjukkan trend pertumbuhan target dan realisasi pendapatan dari tahun 2009-2016.

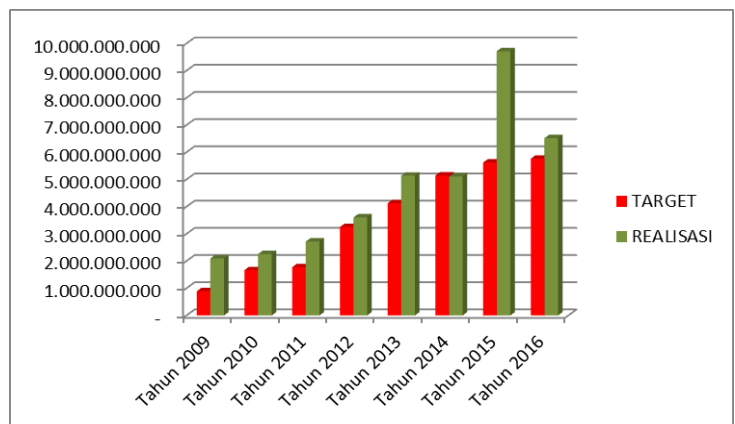

Gambar 1 Trend Pertumbuhan Target dan

Realisasi Pendapatan 2009-2016

Secara keseluruhan pendapatan yang bersumber dari pajak dan retribusi perizinan yang berbayar mengalami peningkatan yang cukup signifikan dari tahun ke tahun. Peningkatan baik dari segi target maupun realisasi. Hal ini sesuai dengan rekap target pendapatan dan realisasi pendapatan DPMPPTSP dari tahun 2009-2016 pada Tabel 1. Terdapat beberapa realisasi pendapatan yang melampaui target yang sudah ditentukan

Berdasarkan hasil wawancara dengan Kepala Dinas Penanaman Modal dan PPSTSP pada tanggal 1 Maret 2017, Bapak I Putu Karuna, SH., yang menyebabkan realisasi tidak memenuhi target pada tahun 2014 karena kurang tepatnya prediksi yang dibuat. Target ditentukan berdasarkan data masa lalu dan melihat realisasi untuk tahun terakhir sesuai dengan insting dan perkiraan sendiri baik itu berkaitan dengan keputusan untuk menaikkan atau menurunkan target berdasarkan pertimbangan tertentu. Menganalisis data dalam jumlah besar jika dilakukan secara manual cukup sulit untuk menentukan kecepatan perhitungan tanpa penggunaan metode yang tepat untuk memprediksi pendapatan dan membutuhkan waktu yang lebih lama serta ketelitian yang tinggi supaya tingkat kesalahan yang ditimbulkan tidak terlalu besar.

Berdasarkan permasalahan tersebut maka perlu adanya suatu sistem yang mampu memberikan rekomendasi kepada pengambil keputusan dalam meramlkan jumlah pendapatan pada periode berikutnya. Peramalan merupakan bagian awal dari pengambilan keputusan. Beberapa pendapat ahli mengenai peramalan diantaranya disampaikan oleh Kusuma, di mana forecasting atau peramalan adalah perkiraan tingkat permintaan satu atau lebih produk selama beberapa periode mendatang ${ }^{[5]}$. Sistem peramalan pendapatan ini nantinya akan memberikan rekomendasi kepada Kepala Dinas dengan tingkat kesalahan tertentu. Dalam penelitian ini digunakan 3 (tiga) metode peramalan yaitu metode Double Moving Average (DMA), Double Exponential Smoothing (DES), dan Least Square (LS). Ketiga metode ini digunakan untuk meramalkan realisasi pendapatan pada periode selanjutnya untuk digunakan sebagai bahan masukan atau rekomendasi kepada Kepala Dinas untuk menentukan target pada periode selanjutnya. 
Tabel 2. Hasil Perbandingan Metode

\begin{tabular}{|c|c|c|c|c|}
\hline No & Metode & MAD & RMSE & MAPE \\
\hline 1. & $D E S$ & 160.687 .789 & 337.018 .146 & $42,79 \%$ \\
\hline 2. & LS & $\mathbf{1 4 0 . 0 7 2 . 1 2 3}$ & $\mathbf{3 1 4 . 6 3 3 . 0 3 4}$ & $\mathbf{3 9 , 6 3} \%$ \\
\hline 3. & $D M A$ & 195.955 .605 & 407.997 .880 & $51,63 \%$ \\
\hline
\end{tabular}

Berdasarkan ringkasan pada tabel tersebut menunjukkan bahwa metode Least Square merupakan metode terbaik untuk melakukan peramalan pendapatan pajak dan retribusi berbayar, terlihat dari nilai MAD, RMSE, dan MAPE terkecil yaitu 140.072.123, 314.633.034 dan 39,63\%. Selain itu menurut Sugiarto, metode Least Square merupakan metode yang paling umum digunakan dalam peramalan untuk data time series untuk melihat trend ${ }^{[6]}$. Menurut Supranto, metode Least Square (kuadrat terkecil) untuk mencari garis trend suatu perkiraan atau taksiran mengenai nilai $a$ dan $b$ dari persamaan didasarkan atas data hasil observasi sedemikian rupa sehingga dihasilkan jumlah kesalahan kuadrat terkecil (minimum) ${ }^{[6]}$. Hal ini sesuai dengan hasil perhitungan yang diperoleh dengan membandingkan metode least square dengan 2 metode peramalan trens lainnya yaitu Double Exponential Smoothing dan Double Moving Average.

Sehingga penulis menggunakan metode Least Square untuk melakukan peramalan dan analisis tren pendapatan di Dinas Penanaman Modal dan PPTSP Kabupaten Buleleng. Sehingga untuk pembahasan selanjutnya metode peramalan yang digunakan adalah Metode Least Square. Berikut ini adalah flowchart dari metode least square.

Langkah-langkah dalam peramalan dengan menggunakan metode Least Square adalah sebagai berikut.

1) Menentukan nilai $X$ dengan melihat jumlah data, data ganjil atau data genap, untuk tahun dasar ditengahtengah data sehingga $\Sigma X=0$. Menurut Budiasih untuk membuat nilai $\sum X=0$ tergantung dari jumlah data tahunnya yaitu genap dan ganjil ${ }^{[8]}$, pedomannya sebagai berikut:

- Untuk n Ganjil

$$
\begin{aligned}
& n=2 k+1 \\
& n-1=2 k \\
& k=\frac{n-1}{2}
\end{aligned}
$$

Untuk menentukan nilai 0 maka $k+1=0$

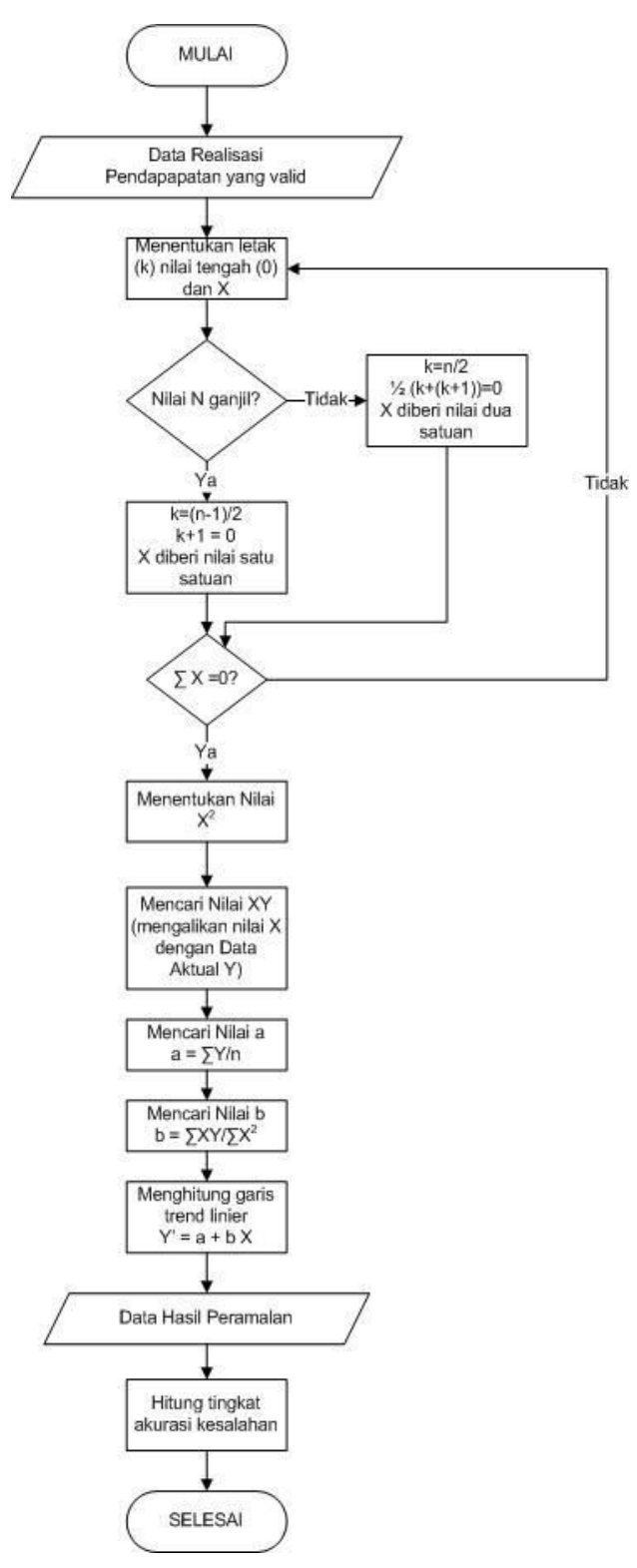

Gambar 2. Flowchart Metode Least Square 
Setelah mendapatkan nilai tengah yaitu 0 , data di atas 0 bernilai $(-)$ sedangkan data di bawah 0 bernilai $(+)$ sehingga $\sum X=0$. Jarak antara dua waktu diberi nilai satu satuan misalnya ....-2,-1,0,1,2, ....

- Untuk n Genap

$n=2 k$

$k=\frac{n}{2}$

Untuk menentukan nilai 0 maka

$\frac{1}{2}(k+(k+1))=0$

Setelah mendapatkan nilai tengah yaitu 0 , data di atas 0 bernilai (-) sedangkan data di bawah 0 bernilai $(+)$. Jarak antara dua waktu diberi nilai dua satuan misalnya ....,-5,-3,$1,1,3,5, \ldots \ldots$

2) Setelah memperoleh nilai $x$, maka dicari nilai $X^{2}$

3) Selanjutnya adalah mencari nilai $X Y$ yaitu dengan mengalikan nilai $X$ dengan nilai data actual $(Y)$.

4) Mencari nilai konstanta a

$$
\begin{aligned}
& \sum Y=n a+b \sum X \\
& \sum Y=n a+b(0) \\
& a=\frac{\sum Y}{n}
\end{aligned}
$$

5) Mencari nilai konstanta $b$

$$
\begin{aligned}
& \sum X Y=a \sum X+b \sum X^{2} \\
& \sum X Y=a(0)+b \sum X^{2} \\
& b=\frac{\sum X Y}{\sum X^{2}}
\end{aligned}
$$

6) Menghitung garis tren linier dapat ditulis sebagai persamaan garis lurus $Y^{\prime}=a+b X$

di mana :

$Y$ : Data historis

$X$ : Parameter pengganti waktu

a : Intersep yaitu besarnya nilai $Y$ bila nilai $X=0$ (Nilai trend periode dasar)
b : Pertambahan trend (slope garis trend, yaitu perubahan variabel $Y$ untuk setiap perubahan satu unit variabel $X$ )
$\mathrm{n}$ : Jumlah Data

Setiap metode peramalan memiliki ketepatan dan tingkat kesulitan masingmasing yang harus dipertimbangkan ${ }^{[7]}$. Oleh karena itu, harus dipilih metode yang paling tepat, yaitu metode yang dapat meminimumkan kesalahan peramalan. Semakin kecil nilai kesalahan, maka akan semakin tepat hasil peramalan yang diperoleh. Dalam penelitian ini digunakan MAD, RMSE dan MAPE untuk menghitung rata-rata kesalahan perhitungan peramalan.

\section{Mean Absolute Deviation (MAD}

MAD merupakan rata-rata kesalahan mutlak selama periode tertentu tanpa memperhatikan apakah hasil peramalan lebih besar atau lebih kecil dibandingkan kenyataannya. Dengan mengetahui nilai MAD kita bisa mengetahui penyimpangan data dari rata-rata atau tingkat kesalahan peramalan. Secara umum, bila residual besarnya merata sepanjang pengamatan, maka MSE yang sebaiknya digunakan ${ }^{[9]}$. Tetapi bila satu atau dua residual yang besar, maka MAD yang sebaiknya digunakan.

Jika diformulasikan maka formula untuk menghitung MAD adalah sebagai berikut:

$$
M A D=\frac{\sum_{t=1}^{n}|X t-F t|}{n}
$$

\section{Root Mean Square Error (RMSE) \\ RMSE digunakan untuk} mengevaluasi kinerja model dalam hal kesesuaian dengan data atau meramalkan data. RMSE menghitung selisih antara nilai yang diprediksi oleh model dan nilai sebenarnya. Menurut Voulgaraki, karena RMSE menghitung selisih antara nilai yang diprediksi oleh model dan nilai sebenarnya 
[10]. RMSE tidak memiliki standar nilai minimal untuk mengetahui kinerja model, berbeda dengan MAPE. Secara sederhana, RMSE merupakan metode untuk menghitung bias dalam model peramalan $^{[10]}$.

$$
R M S E=\sqrt{M S E}=\sqrt{\frac{\sum_{t=1}^{n}(X t-F t)^{2}}{n}}
$$

di mana:

$\mathrm{n}$ : nilai periode waktu

Xt : nilai sebenarnya pada periode ke-t

Ft : nilai peramalan pada periode ke-t

\section{Mean Absolute Percentage Error (MAPE)}

MAPE menunjukkan rata-rata kesalahan absolut prakiraan dalam bentuk persentasenya terhadap data aktualnya. MAPE digunakan untuk mengevaluasi ketepatan peramalan menggunakan kesalahan dalam bentuk persentase. Semakin kecil nilai MAPE berarti nilai taksiran semakin mendekati nilai sebenarnya, atau metode yang dipilih merupakan metode terbaik. Perhitungan rata-rata kesalahan dengan MAPE biasanya lebih banyak dipakai karena mudah dibaca (karena dalam bentuk persentase $)^{[10]}$.

$$
M A P E=\frac{\sum_{t=1}^{n}\left|\frac{X t-F t}{X t}\right|}{n} \times 100 \%
$$

di mana:

$\mathrm{n}$ : nilai periode waktu

$\mathrm{Xt}$ : nilai sebenarnya pada periode ke-t

$\mathrm{Ft}$ : nilai peramalan pada periode ke-t

Semakin rendah nilai MAPE, maka dapat dikatakan model peramalan memiliki kemampuan yang baik. ${ }^{[10]}$ Range nilai untuk MAPE dapat dilihat pada Tabel 3.
Tabel 3. Signifikansi Nilai MAPE

\begin{tabular}{|c|l|}
\hline MAPE & \multicolumn{1}{|c|}{ Signifikansi } \\
\hline$<10 \%$ & $\begin{array}{l}\text { Kemampuan peramalan sangat } \\
\text { baik }\end{array}$ \\
\hline $10-20 \%$ & Kemampuan peramalan baik \\
\hline $20-50 \%$ & $\begin{array}{l}\text { Kemampuan peramalan } \\
\text { layak/memadai }\end{array}$ \\
\hline$>50 \%$ & $\begin{array}{l}\text { Kemampuan peramalan sangat } \\
\text { buruk }\end{array}$ \\
\hline
\end{tabular}

Berikut ini adalah contoh perhitungan peramalan dengan metode least square

1. Menentukan nilai $X$ dengan melihat jumlah data, data ganjil atau data genap, untuk tahun dasar ditengahtengah data, karena data yang digunakan adalah data dalam jumlah ganjil, maka digunakan rumus yaitu:

$$
\begin{aligned}
& k=\frac{n-1}{2} \\
& k=\frac{99-1}{2} \\
& k=49
\end{aligned}
$$

Untuk menentukan nilai 0 maka

$$
\begin{aligned}
& k+1=0 \\
& 49+1=0 \\
& 50=0
\end{aligned}
$$

Setelah mendapatkan nilai tengah yaitu 0 pada data ke-49, data di atas 0 yaitu dari 1-49 bernilai (-) sedangkan data di bawah 0 yaitu data $51-99$ bernilai $(+)$ sehingga $\Sigma X=0$. Jarak antara dua waktu diberi nilai satu satuan misalnya $\ldots-2,-1,0,1,2, \ldots .$.

2. Setelah memperoleh nilai $x$, maka dicari nilai $X^{2}$

$X_{1}=-49 *-49=2.401$

3. Selanjutnya adalah mencari nilai $X Y$ yaitu dengan mengalikan nilai $X$ dengan nila data actual $(\mathrm{Y})$.

$$
\begin{aligned}
X_{1} & =-49 * 123.636 .501 \\
& =-6.058 .188 .549
\end{aligned}
$$

4. Mencari nilai konstanta a

$$
\begin{aligned}
& a=\frac{\sum Y}{n} \\
& a=\frac{38.958 .876 .070}{99}
\end{aligned}
$$




$$
a=393.524 .001
$$

5. Mencari nilai konstanta $b$

$$
\begin{aligned}
b & =\frac{\sum X Y}{\sum X^{2}} \\
b & =\frac{513.067 .907 .109}{80.850} \\
b & =6.345 .923
\end{aligned}
$$

6. Menghitung garis tren linier dapat ditulis sebagai persamaan garis lurus

$$
\begin{aligned}
Y^{\prime} & =a+b X \\
Y^{\prime} & =393.524 .001+6.345 .923 X \\
Y^{\prime} & =393.524 .001+6.345 .923(49) \\
Y^{\prime} & =710.820 .171
\end{aligned}
$$

7. Menentukan rata-rata kesalahan peramalan

$$
\begin{aligned}
& M A D=\frac{\sum_{t=1}^{n}|X t-F t|}{n} \\
& M A D=\frac{13.867 .140 .224}{99} \\
& M A D=140.027 .123 \\
& M S E=\frac{\sum(X t-F t)^{2}}{n} \\
& M S E=\frac{9.800 .400 .681 .532 .510 .000}{99} \\
& M S E=98.993 .946 .278 .106 .100 \\
& R M S E=\sqrt{M S E}=\sqrt{\frac{\sum_{t=1}^{n}(X t-F t)^{2}}{n}} \\
& R M S E=\sqrt{98.993 .946 .278 .106 .100} \\
& R M S E=314.633 .034 \\
& M A P E=\frac{\sum_{t=1}^{n}\left|\frac{X t-F t}{X t}\right|}{n} x 100 \% \\
& M A P E=\frac{3924}{99} x 100 \% \\
& M A P E=39,63 \%
\end{aligned}
$$

Dalam SPK peramalan pendapatan di Dinas Penannaman Modal dan PPTSP Kabupaten Buleleng terdapat 3 (tiga) pengguna sistem yaitu Bendahara Penerimaan, Admin, dan Kepala Dinas. Pada dasarnya ketiga pengguna sistem ini memiliki aktivitas yang sama yaitu login dan melihat data realisasi pendapatan. Bendahara penerimaan hanya bertugas untuk menginputkan data jumlah penerimaan pendapatan per bulan sesuai dengan yang dibayarkan oleh pemohon izin. Selanjutnya Tanda Bukti Pembayaran atau TBP yang berupa kwitansi pembayaran diserahkan kepada PPK (Pejabat Penatausahaan Keuangan) selaku Admin untuk dijadikan dasar dalam validasi pendapatan karena bisa saja pada bendahara penerimaan terjadi salah input, untuk itu menjadi tugas admin untuk memvalidasi data pendapatan agar benarbenar valid dengan memasukkan data tanggal validasi. Proses peramalan juga dilakukan oleh admin, di mana sistem akan menampilkan hasil peramalan beserta rata-rata kesalahan. Kepala Dinas juga bisa melihat rekap target setiap tahunnya, realisasi pendapatan yang valid serta hasil peramalan beserta rata-rata kesalahannya sehingga nantinya bisa digunakan sebagai rekomendasi dalam menentukan target pendapatan pada tahun berikutnya.

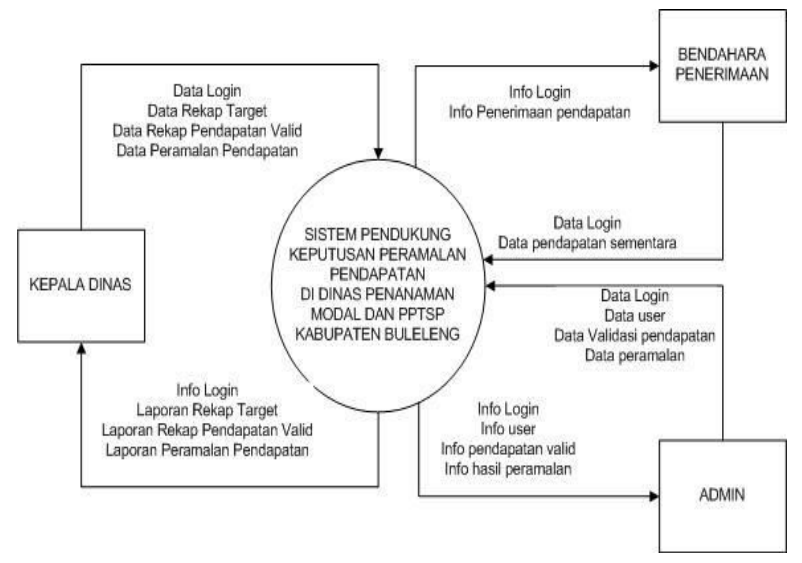

Gambar 3. Digram Konteks

SPK Peramalan pendapatan ini diirancang menggunakan 5 buah tabel yaitu tabel target untuk menyimpan data target, tabel pendapatan untuk menyimpan data pendapatan, tabel pengguna untuk menyimpan data pengguna sistem, tabel user untuk menyimpan data user pengguna yang memiliki hak akses ke sistem serta tabel hasil peramalan untuk menyimpan data hasil peramalan. Berikut adalah 
relasi tabel dalam SPK Peramalan pendapatan ini.

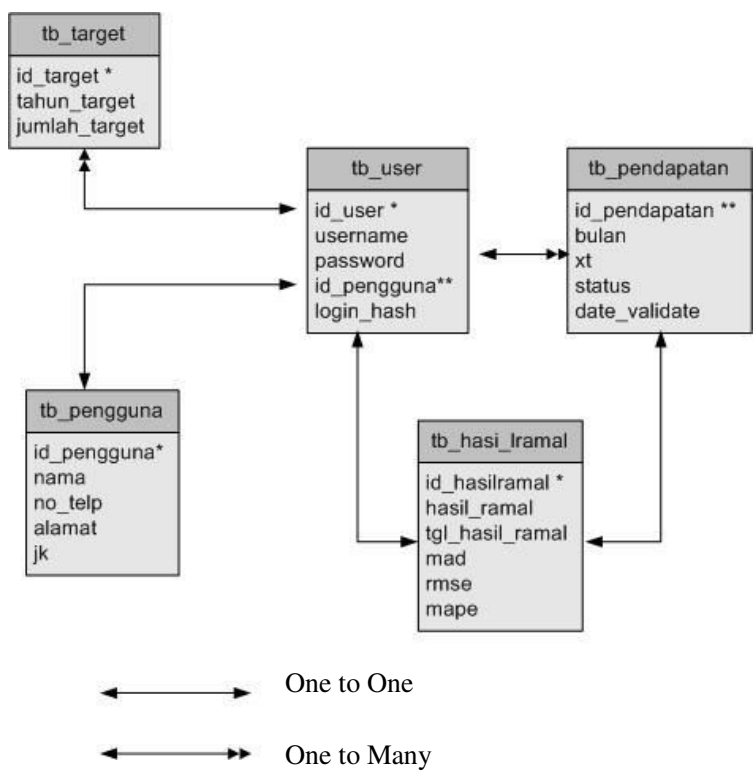

Gambar 4. Relasi Tabel SPK Peramalan Pendapatan

\section{HASIL DAN PEMBAHASAN}

a. Implementasi Antarmuka Halaman Login

Halaman login ini berfungsi sebagai halaman yang akan mengecek kebenaran user telah terdaftar atau belum di dalam sistem dengan hak aksess tertentu. Implementasi antarmuka halaman login dapat digambarkan seperti Gambar 5 berikut.

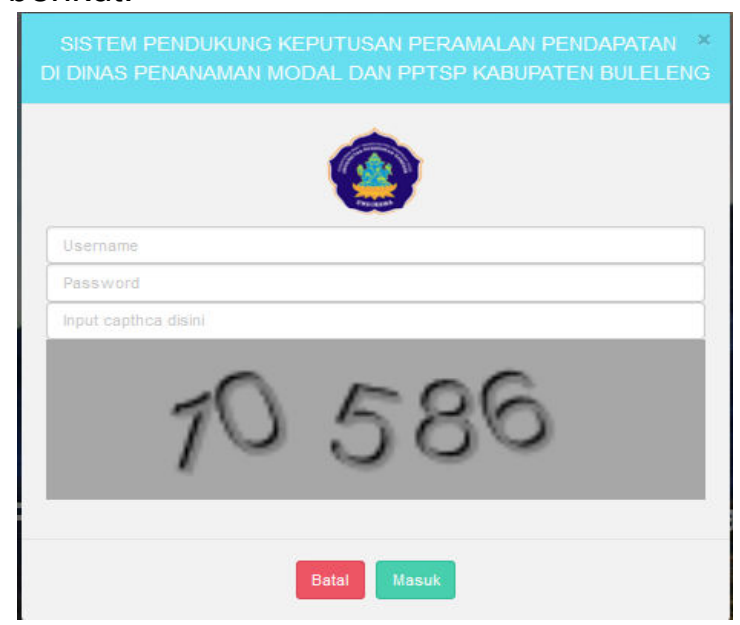

Gambar 5. Implementasi Antarmuka Halaman Login b. Implementasi Antarmuka Halaman Utama Bendahara Penerimaan

Pada halaman ini akan ditampilkan data pendapatan yang sudah divalid oleh admin di mana data ini tidak bisa diubah lagi, data yang bisa diubah adalah data realisasi pendapatan yang belum divalidasi. Bendahara juga bisa menginputkan data realisasi pendapatan. Implementasi antarmuka halaman login dapat digambarkan seperti Gambar 6 berikut.

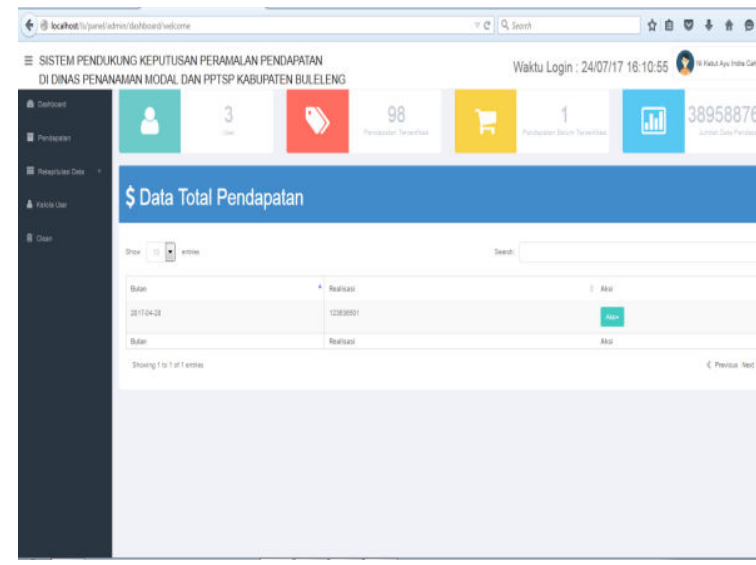

Gambar 6. Implementasi Antarmuka Halaman Admin

c. Implementasi Antarmuka Proses Perhitungan Least Square

Halaman ini dilakukan oleh admin untuk melakukan perhitungan peramalan seperti Gambar 7 berikut.

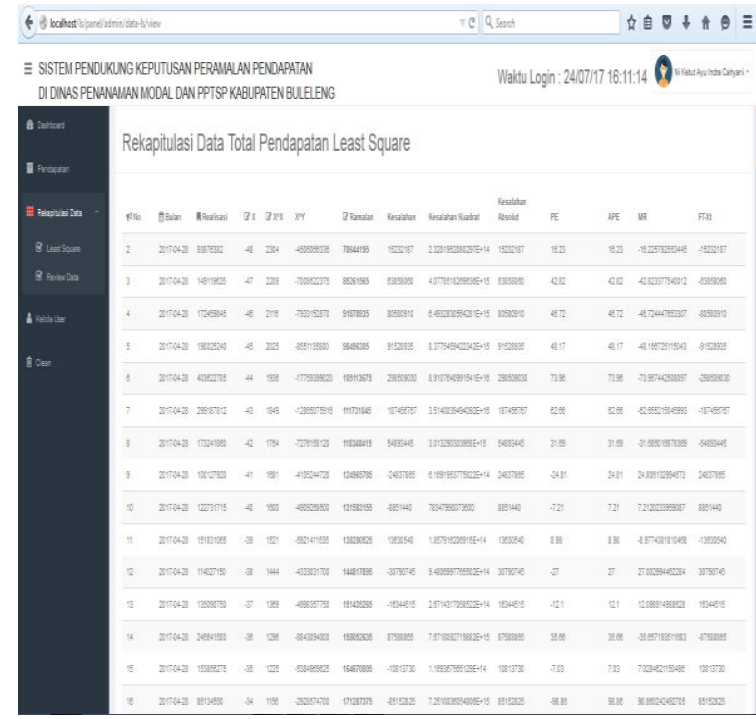

Gambar 7. Implementasi Antarmuka Perhitungan Least Square 
d. Implementasi Antarmuka Halaman Kepala Dinas

Halaman ini dilakukan oleh kepala dinas untuk melihat data target, data pendapatan dan data hasil peramalan beserta rata-rata kesalahan, serta mencetak laporan. Implementasi antarmuka halaman login dapat digambarkan seperti Gambar 8 berikut.

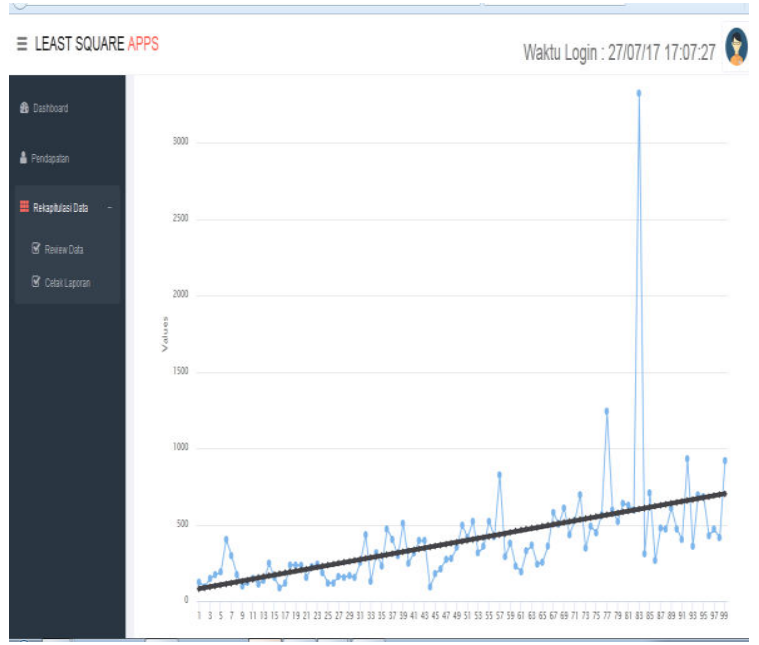

Gambar 8 Implementasi Antarmuka Halaman Kepala Dinas

Pengujian perangkat lunak terdiri dari black box testing, white box testing dan pengujian tingkat keakuratan sistem. Pengujian black box, di mana hasilnya semua fungsi atau fitur yang diujikan dapat berjalan dengan baik, respon pengguna terhadap sistem sangat baik serta sistem sangat berguna dan bermanfaat bagi pengguna, dengan nilai rata-rata respon responden yang memilih skor 5 yang mewakili pernyataan sangat tepat, sangat sesuai, sangat jelas, sangat menarik, sangat mudah adalah sejumlah $71,11 \%$ dan $28,89 \%$ memilih jawaban dengan skor 4 yaitu pernyataan tepat, sesuai, jelas, menarik, mudah. Pengujian white box menyatakan bahwa semua source code dan logika-logika yang diterapkan sudah berjalan sesuai dengan penjelasan pada masing-masing pengujian. Pengujian akurasi sistem diperoleh hasil bahwa sistem ini memiliki tingkat akurasi 66,34\% dengan rata-rata kesalahan peramalan sebesar $33,66 \%$.

\section{SIMPULAN}

Dari analisis perancangan dan implementasi yang penulis lakukan, maka diperoleh kesimpulan bahwa Sistem Pendukung Keputusan Peramalan Pendapatan di Dinas Penanaman Modal dan PPTSP Kabupaten Buleleng dirancang dengan menggunakan flowchart dan data flow diagram dan dalam proses perhitungan peramalan menggunakan metode least square. Sistem Pendukung Keputusan Peramalan Pendapatan di Dinas Penanaman Modal dan PPTSP Kabupaten Buleleng diimplementasikan dengan menggunakan bahasa pemrograman PHP, basis data MySQL dan Javascript. Dari hasil implementasi dilakukan pengujian yaitu pengujian black box, white box dan uji akurasi sistem yaitu sebesar $66,34 \%$ dengan rata-rata kesalahan peramalan sebesar $33,66 \%$.

Berdasarkan hasil implementasi dan pengujian yang dilakukan maka penulis menyarankan beberapan hal terkait dengan pengembangan sistem berikutnya yaitu pengembangan dengan menggunakan metode lain sehingga diketahui kelebihan dan kekurangan sistem ini. Karena data realisasi pendapatan setelah dilakukan uji normalitas ternyata hasinya data berdistribusi tidak normal bisa sehingga pembaca bisa menambahkan fitur untuk transformasi data sehingga data yang tidak normal bisa dinormalisasi terlebih dahulu secara otomatis oleh sistem, serta pengembangan sistem dalam bentuk mobile.

\section{REFERENSI}

[1] Aji, B.P. Analisis Sumber Pendapatan Asli daerah (PAD) dalam Pelaksanaan Otonomi Daerah di Kabupaten Buleleng. e-Journal Bisma Universitas Pendidikan Ganesha. 2015; 3: halaman 2.

[2] Mudi, H.M. Sistem Pendukung Keputusan Peramalan Penjualan Mobil Menggunakan Metode Trend Moment (Studi Kasus PT. Hadji Kalla Cabang Kendari). 2016:halaman 1. 
[3] Anggraeni, M. A. Analisis Peramalan Penjualan Produk Sepeda Motor Matik Tipe Scoopy dengan Metode Kuadrat Terkecil pada PT. Mertha Buana Motor Tahun 2015. Jurnal Jurusan Pendidikan Ekonomi (JJPE), (2015); 5(1):halaman 2.

[4] Yosep Yonhy, R. G. Metode Trend Non Linear Untuk Forecasting Jumlah Keberangkatan Tenaga Kerja Indonesia di Kantor Imigrasi Kelas II Kabupaten Nunukan. Jurnal Eksponensial. 2013; 4(1):halaman 47.

[5] Sianipar, M. Perancangan Aplikasi Forecasting Persediaan Bahan Baku Produksi Tapioka Pada PT Hutahaean dengan Menggunakan Metode Least Square. Jurnal Pelita Informatika Budi Dar. 2014; 8(3): halaman 43.

[6] Muqtadiroh, F. A. (28 Maret 2015). Analisis Peramalan Penjualan Semen Non-Curah (ZAK) PT. Semen Indonesia (Persero) TBK pada Area Jawa Timur. Seminar Nasional Teknologi Informasi dan Komunikasi (SENTIKA 2015). Yogyakarta. halaman 310.

[7] Makridakis, S. \&. Metode dan Aplikasi Peramalan (Jilid 1 ed.). Jakarta: Binarupa Aksara. 1999:halaman 31.

[8] Ihsan, M. dkk. Perancangan Aplikasi Peramalan Penjualan Motor Honda Menggunakan Metode Least Square (Studi Kasus: PT. HD Motor 99 Gresik). 2016:halaman 3.

[9] Abdullah, W.). Peramalan Penjualan Air Bersih dan Formulasi Strategi Perusahaan Daerah Air Minum. Jurnal Ekonomi dan Studi Pembangunan, 2014; 15(1): halaman 81.

[10] Hutasuhut, A. H. Pembuatan Aplikasi Pendukung Keputusan untuk Peramalan Persediaan Bahan Baku Produksi Plastik Blowing dna Inject Menggunakan Metode ARIMA (Autoregressive Integrated Moving Average) di CV. Asia. Jurnal Teknik Pomits. 2014; 3(2):halaman 70-171. 